\title{
Destination image and crime in Mexico: An analysis of foreign government travel advice
}

\author{
J. Carlos Monterrubio*
}

Universidad Autónoma del Estado de México, Mexico

\begin{abstract}
Destination image has been recognised as an influential component of travel decision processes. Although organic sources of information play an important role in shaping destination image, researchers have often ignored the types of sources and the information they deliver. In particular, official websites where government travel advice is given, especially in relation to crime, have been widely excluded from scholarly research. This paper analyses the relationship between crime-related travel advice given by foreign governments and Mexico's destination image. Qualitative content analysis of official websites from the US, Canada, the UK and Spain reveals that the travel advice given relates largely to the violence and insecurity that Mexico is currently experiencing. "No advisory in effect", "Exercise caution" and "Defer non-essential travel" are messages commonly found in the governments' travel advice about Mexico.
\end{abstract}

Key words: destination image, crime, travel advice, Mexico, qualitative content analysis

\section{Introduction}

It is well documented that destination image is an influential part of the traveller's decision process. Analysing destination image is thus important for exploring the mental and emotional constructs of both potential and actual travellers to specific destinations. Also, it is useful for understanding how destination choice is made and how tourists behave once they are at the destination. For these reasons, destination image has become one of the most studied topics in the literature, at least in the tourism literature in English.

Destination image is influenced by several factors such as an individual's motivations, previous travel experience, films, advertisements, perceived safety, to name but a few. However, little has been investigated in terms of the information provided by, and the effect of, sources that have not been exclusively created to market tourism. That is, the type of information and the potential influence on image formation of sources such as films, news, documentaries and the internet have not been sufficiently elucidated.

This paper focuses on the type of online travel advice provided by foreign governments. Due to the potential credibility and the wide penetration into potential and actual tourism markets in several parts of the world, official online information regarding governments' travel and tourism advice deserves specialised academic attention. The favourable and unfa-

* J. Carlos Monterrubio holds a PhD in tourism from the Manchester Metropolitan University, UK. He is currently a lecturer and tourism researcher at the Autonomous University of the State of Mexico, Mexico. His research interests are the social aspects of tourism. He has published two books on tourism impacts and several journal articles on related topics.

E-mail: jcmonterrubio@yahoo.com.mx 
vourable contribution to image formation by foreign government travel advice can be used for improving the image of specific destinations especially those in which social issues such as crime remain a serious concern.

Bearing this in mind, this paper analyses the travel advice given by foreign governments as related to crime and destination image in Mexico. In this vein, the purpose of this research is twofold. Firstly, it aims to contribute to the understanding of government travel advice as information sources for image formation; secondly, it aims to contribute to the development of the study of destination image in the so-called developing countries, particularly Mexico, where there is a significant paucity in the study of the topic in question.

This paper is structured as follows. First, a literature review on destination image and its relation to crime issues is presented. In particular, both cognitive and affective components and the role of information sources in destination image are discussed. Then, an overview of Mexico in terms of tourism and crime issues is provided, so as to give the contextual elements needed to understand how tourism, crime and image are interrelated. Next, the description of the study is presented; the identification of websites' content for analysis and the specific methodological approach adopted for this study are described. Finally, findings, implications and conclusions are presented.

\section{Literature Review}

\subsection{Destination image as a research topic}

The study of destination image appears to be one of the most frequent topics of scholarly analysis, at least in the academic traditions of the so-called developed countries. For almost four decades, several issues have been specifically studied around the world. These include, but are not limited to, the review of existing literature on destination image (Chon, 1990; Echtner \& Ritchie, 1991; see also Gallarza, et al., 2002; Pike, 2002), models representing the determinants of destinations' image formation (Baloglu \& McCleary, 1999), models featuring the complex, multiple, relativistic and dynamic nature of destination image (Gallarza, et al., 2002), and models explaining the different factors which form the post-visit image of a destination (Beerli \& Martín, 2004).

According to the literature review of main tourism journals undertaken by Gallarza, et al. (2002), the major topics covered by the begin- ning of the 2000s were conceptualization and dimensions; destination image formation processes; assessment and measurement of destination image; influence on destination image; destination image change over time; active and passive role of residents in image research and; destination image management policies. It is also worth noticing that most of the studies on destination image derive from the perspective and the experience of developed countries. In his review of literature on the topic, Pike (2002) observed that the most popular region for the study of destination image was North America, which was discussed in 58 academic papers. This was followed by UK/Europe (45), Asia (25), Australasia (19), Africa (14), Central America/ Caribbean (9), South Pacific (5) and South America (1). This reveals that little is known about issues of destination image in developing countries, including Mexico.

\subsection{Definition}

Although destination image has often been the focus of academic enquiry, it is of interest to notice that its conceptualisation lacks general agreement. Whilst there may be as many definitions of destination image as academics devoted to its study (Gallarza, et al., 2002), as Beerli and Martín (2004) observe, authors have not tended to conceptualise the term precisely. This can be easily observed when reviewing some of the existing literature. The work of Gallarza, et al. (2002), in particular, demonstrates that destination image conceptualisations are various and diverse to some extent. By recognising that there exist several disciplinary approaches for studying destination image, the authors identify several attempts defining the concept in terms of impressions, understanding, imaginations, mental constructs, ideas or conceptions, beliefs, representations, and even prejudice. Therefore, image is generally considered as "an attitudinal construct consisting of an individual's mental representation of knowledge (beliefs), feelings, and global impression about an object or destination" (Baloglu \& McCleary, 1999, p. 870). For Baloglu and McCleary (1999) destination image is thus closely associated to cognitive constructions and emotional responses derived from such constructions.

"The perceptual/cognitive evaluations refer to the beliefs or knowledge about a destination's attributes whereas affective evaluation refers to feelings toward, or attachment to it. A common agreement is that this depends on a cog- 
nitive evaluation of objects and the affective responses are formed as a function of the cognitive responses. An overall image of a place is formed as a result of both perceptual/cognitive and affective evaluations of that place." (Baloglu \& McCleary, 1999, p. 870).

\subsection{Destination image formation}

While existing research has shown that image is an important factor in understanding tourists' destination selection process, and that initial image formation before the trip is the most important phase in the process of destination choice, very little is known about how destination images are actually constructed and what the influential factors in such constructions exactly are. In this vein, Lepp, et al. (2011) claim that two types of image are generally identified: cognitive and affective. While the former refers to perceptions of the sociocultural and natural and built (e.g. infrastructure) aspects of a destination, affective image reflects the feelings and emotions individuals have about a destination, including perceived safety and security which have been identified as the most important attributes a destination can offer (Floyd \& Pennington-Gray, 2004). While this classification recognises that image is formed both cognitively and emotionally, it should be borne in mind that cognitive representations and emotional responses of an individual are constructed, framed and shaped differently from one individual to another and from external factors to which individuals are exposed at different levels.

Specialists have commonly agreed that image is mainly formed by two major factors: personal factors and stimulus factors (Baloglu \& McCleary, 1999). While the former refer to tourism motivations, previous travel experience and socio-demographics, the latter are related to various forces that may significantly influence the cognitive constructions and affective evaluations of a destination; these forces are called information sources.

\subsection{Information sources}

Information sources "refer to the amount and diverse nature of information sources to which individuals are exposed“ (Beerli \& Martín, 2004, p. 661). Gartner (1993) claims that information sources act independently to form images in the minds of individuals. Such information sources can be of different types and may be found in individuals' own knowledge and experience, conventional advertising in the mass media, information delivered institutionally, tour operators, promotional activities, destination reports, mass-media broadcasting news, documentaries, television programmes, films, among others, about a specific destination.

Therefore, destination image is formed by processing and assessing information from various sources, particularly from those to which individuals are exposed. These sources can be categorised into organic and induced sources. Organic sources include books, news, films, actual visits to destinations, to mention but a few, and do not have a vested interest in promoting the destination in question; on the other hand, induced sources include travel brochures, advertisement, posters and the internet and are a means of communicating marketing messages about the destination (Stepchenkova \& Morrison, 2006). Induced sources are quite relevant since, as Stepchenkova and Morrison (2006) argue, they form destination images in the absence of actual visitation to the destination. While this categorisation may be useful in identifying the importance of influential factors in destination image formation, it is observed that only a small amount of research has addressed the specific roles -either real or potential- that each of these sources (organic and induced) has on image formation. Limited analysis also exists about the type of information delivered by both sources. Most importantly perhaps, it remains largely unknown how both sources go about determining the types of images projected about countries.

While it is has been hypothesised that the type of information source used significantly influences cognitive evaluations (Baloglu \& McCleary, 1999), it is reasonable to believe that the influence that each of these information sources has on image formation will not be the same. As Choi, et al. (2007) acknowledge, image formation agents, including information sources, affect the destination process in a different manner. This is basically due to the fact that individuals may be exposed to several sources of information simultaneously and such information will have different impact on individuals' processes. The effect of sources will depend on how such information is perceived and integrated to that previously accumulated from other sources. While some sources may be more powerful in shaping destination image, and others may partly contribute to such formation, others may not play any role at all. It is reasonable to believe that while induced sources are specifically designed for particular markets, 
organic sources may be so powerful that they can be even more influential and determinant in image formation cognitive processes. Organic images, although not being specifically designed for marketing purposes, may become more relevant in the process of destination choice.

In this context it is important to notice that there is very little scholarly examination of the specific influence that organic information sources may have on the formation of destination image. Furthermore, there is a scarcity of studies on the type of information delivered by potentially influential sources. Particularly there is very limited analysis of the type of information delivered through the internet by government bodies influencing -positively or negatively- the image of some international destinations. Analysing government websites (information sources) as related to destination image both for self presentation and for other destinations' image, seems to become more and more important due to the number of countries that maintain official tourism websites around the world (see for example Lepp, et al., 2011; Mohammed, 2004).

\subsection{Destination image and crime}

When focusing on the process of destination image formation, Beerli and Martín (2004) state that there are several dimensions and attributes of the destination that determine the perceived image. The authors divide them into nine attributes:

1. Natural resources such as weather, beaches flora and fauna;

2. General infrastructure including quality of roads, transport facilities and development of telecommunications;

3. Tourist infrastructure consisting of accommodation, restaurants, access to destination, etcetera;

4. Tourist leisure and recreation, for example, entertainment, sport activities, night life, shopping;

5. Culture, history and art such as museums, festivals, gastronomy and religion;

6. Natural environment including beauty of scenery, overcrowding, air and noise pollution;

7. Social environment such as hospitality and friendliness, poverty and language barriers;

8. Atmosphere of the place which can be exotic, stressful, pleasant, etcetera, and;

9. Political and economic factors which include issues such as political stability, safety (mainly defined as crime rate) and terrorist attacks (Beerli \& Martín 2004)

While all these attributes can play an important role in image formation processes, political and social factors, particularly those associated with risks, seem to be very relevant issues in the process of destination image and in the level of likelihood of visitation. Considering that risks can be financial, social, psychological, physical, functional and situational (Korstanje, 2009), research has identified four major risk factors in travel and tourism contexts: terrorism, war and political instability, health concerns and crime (Lepp \& Gibson, 2003). Although it has been stated that some tourists may judge specific destinations as risky without worrying about travelling to these destinations (Larsen, et al., 2009), according to Sirakaya, et al. (1997), those destinations that are perceived as safe are associated with a higher probability of visitation whilst those with perceived risks are related to lower chances of visitation. George (2003) suggests that when tourists feel unsafe or threatened at a destination, they can develop unfavourable impressions of the destination. In turn this can result in the decline of tourists to the area and therefore in damage to the local tourism industry. The author argues that this can happen: 1) when potential tourists may decide not to visit the destination based on its reputation for having a high crime rate; 2) when tourists feel unsafe at the destination and they may not participate in near-by activities; and 3) when tourists who feel unsafe are neither likely to return to nor to recommend the destination to others. The perceived levels of crime, mainly through organic sources, may thus potentially deter tourists from visiting particular destinations which in turn brings other implications along.

"The implications of terrorist activity [and other related activities] for destinations are obviously wide-ranging: reduced tourist arrivals, reduced investment in tourism infrastructure, job losses, and increased tourist fees to pay for increased security, to suggest but a few" (Wall and Mathieson, 2006: 246).

The risks associated to tourism destination image have been well documented. When investigating images and risks associated with Uganda, Lepp, et al. (2011) claim that certain regions in the world, including Africa and Middle East, have been perceived as risky destinations. In the case of Africa, the authors 
state that political and social instability, poor governance, war, terrorism and crime, to mention some, are perceived risks associated to tourism in the Continent. In the particular case of Uganda, their study revealed an organic image of the country deeply influenced by perceptions of risks; the image of the country "emerges as a place somewhere in Africa characterized by poverty, war and civil unrest, disease, and hunger" (Lepp, et al., 2011, p. 679).

A variety of topics particularly related to tourism and crime has been covered by the literature. Brunt, et al. (2000) observed that there have been six broad areas of interest in the relationships between tourism and crime. Research has focused on tourist areas as areas of high crime; tourists as victims; tourists as offenders; tourism generating higher levels of illegal activity; terrorism and tourism; and policy responses to tourism and crime. What can be noticed too is the fact that tourism research on crime issues has been focused mainly on how tourists become victims of crime in destinations. Even bearing in mind the topics discussed in the previous sections, it is still reasonable to say that the relationships between crime, destination image and information sources have not been researched enough. Specifically, the potential role that official advice about the risks associated with international travel/tourism and organised crime plays in the formation of destination image of Third World Countries, particularly Mexico, remains largely unknown.

\section{Mexico, tourism and crime}

In the last years, Mexico has figured among the world's ten top tourism destinations ranked by international tourism arrivals. According to the World Tourism Organization (UNWTO, 2012), Mexico ranks tenth in the world by arrivals. In 2009 the number of international tourists was 22.3 million; in 2010 a total of 23.3 million tourists arrived in Mexico while in 2011 23.4 million international tourists visited the country. As far as domestic tourism is concerned, during the last 12 years, there have been approximately 140 million tourism trips within the country (SECTUR, 2007).

The importance of tourism in the country is also mirrored in the amount of international receipts, which, in 2009, 2010, 2011 and 2012, totalled USD 11,513, 11,992, 11,869 and 12,720 million, respectively (Data Tur 2013). Tourism thus represents a significant economic value for Mexico as it has meant almost 9\% of Gross Domestic Product. The role that tourism has in the country is relevant and will continue to be so as it is forecast that in the year 2020 Mexico will remain the third destination of the Americas with almost 50 million international arrivals (UNWTO, 2000).

During the first semester of 2011, 5.4 million international visitors arrived in the country by air, out of which $57.4 \%$ came from the United States of America and 18.2\% from Canada. In this vein, by 2010 Mexico was the country most visited by North American tourists (SECTUR 2011) (see Table 1). If we take into account the assertion that the great majority of international travel takes place within the traveller's own region (UNWTO, 2012, p. 12), it is then expected that the United States of America and Canada will remain the most important tourist generating countries for Mexico for many years to come.

Mexico's popularity is closely associated with the large variety attractions offered to tourists such as, for instance, activities related to archaeology, architecture, arts and crafts, nature, adventure, history, gastronomy, sun and beach, and traditions and festivities, which can be found all over the country although the most tourist-oriented are highly concentrated in the main tourism destinations (see Table 2).

Official induced sources, such as the Mexican Tourism Board, offer Mexico's self presentations based on several tourism attractions. This can be observed in the following official website excerpts:

"Make of Mexico the excuse for your next vacation and get your senses ready for an experience full of magic, color and warmth. Come and fall in love with Mexico.

Again and again, Mexico will surprise you with new experiences: a different flavor, a new adventure, a spot waiting for centuries to enchant you. We're waiting for you.

Since almost every known ecosystem is found in Mexico, there's no other country in North or Central America that offers so much for adventure travelers [...] Take a walk on Mexico's wild side-it's an adventure that never ends." (www.visitmexico.com, accessed 04.03.13)

While official websites aim to provide actual and potential tourists with a favourable image of the country, Mexico is going through sociopolitical challenges that have become a serious issue for both national residents and visitors. It 
Table International arrivals (by air) in Mexico by country. Source: Data Tur (2013)

\begin{tabular}{|l|l|r|r|r|r|c|}
\hline & \multicolumn{1}{|c|}{ Country } & $\mathbf{2 0 0 8}$ & $\mathbf{2 0 0 9}$ & $\mathbf{2 0 1 0}$ & $\mathbf{2 0 1 1}$ & $\mathbf{2 0 1 2}$ \\
\hline 1 & United States & $5,810,019$ & $5,383,499$ & $5,907,533$ & $5,728,166$ & $5,941,914$ \\
\hline 2 & Canada & $1,135,001$ & $1,222,410$ & $1,460,418$ & $1,563,150$ & $1,571,544$ \\
\hline 3 & United Kingdom & 311,113 & 257,367 & 295,831 & 330,072 & 363,142 \\
\hline 4 & Spain & 284,512 & 215,669 & 287,163 & 279,531 & 278,811 \\
\hline 5 & Argentina & 126,130 & 127,107 & 170,467 & 200,694 & 251,221 \\
\hline 6 & Brazil & 76,491 & 68,211 & 117,658 & 196,267 & 248,900 \\
\hline 7 & France & 208,284 & 164,236 & 170,250 & 186,780 & 202,855 \\
\hline 8 & Germany & 158,050 & 140,754 & 163,266 & 165,136 & 172,841 \\
\hline 9 & Colombia & 67,378 & 68,493 & 102,177 & 125,882 & 163,722 \\
\hline 10 & Italy & 67,378 & 108,547 & 133,292 & 150,691 & 156,533 \\
\hline
\end{tabular}

thus represents a serious challenge for tourism. Particularly, organised crime in specific areas has seriously threatened individuals' security. Organised crime, in any of its forms including trafficking in drugs, firearms and persons, threatens peace and human security and damages economic, social, cultural, political and civil development of societies (UNODC, 2013).

In this context, Mexico currently confronts one of the greatest threats to its democratic governance in history. The threat is posed by criminal groups especially by politically savvy, hyper-violent drug-trafficking organizations, currently inflicting unprecedented damage in several regions and spreading insecurity throughout the country (Bailey, 2010).
"What brings [organised crime] to a level to threaten democratic governance is its rapid recent growth and aggressiveness. This is due to the confluence of large supplies of violent entrepreneurs and weapons, financed by domestic and foreign markets for illegal drugs, all in the context of slow or even negative economic growth. What in the past had been a chronic but tolerable problem of public security has passed the tipping point to become a genuine threat to national security and democratic governance” (Bailey, 2010, p. 327).

The effects of organized crime have certainly reached the tourism sector. In the case of Acapulco, for example, which is the municipality

Table Main tourism destinations in Mexico. Source: CESTUR (2011)

\begin{tabular}{|c|c|c|c|}
\hline Category & Destination & Category & Destination \\
\hline \multirow{13}{*}{ Cities } & Cuernavaca & \multirow{13}{*}{ Beaches } & Acapulco \\
\hline & Mexico City & & Cancun \\
\hline & Guadalajara & & Cozumel \\
\hline & Guanajuato & & Huatulco \\
\hline & Merida & & Los Cabos \\
\hline & Monterrey & & Mazatlan \\
\hline & Morelia & & Nuevo Vallarta \\
\hline & Nuevo Laredo & & Puerto Vallarta \\
\hline & Oaxaca & & Riviera Maya \\
\hline & Puebla & & Tampico \\
\hline & Querétaro & & Veracruz \\
\hline & San Cristobal & & Zihuatanejo \\
\hline & Tijuana & & \\
\hline
\end{tabular}


that had the highest number of homicides in the whole country in 2012, tourism has been negatively impacted by crime issues. In Acapulco, nightlife is one of the main attractions and it has been seriously affected by insecurity. The frequent fights among drug cartels have dramatically increased the rates of homicide, kidnapping for ransom in the destination since 2007. Hotel owners have witnessed how tourism has considerably decreased in the last three years. In 2011 just $30 \%$ of hotel occupation was reported. Insecurity has significantly affected international tourism in the destination. It is why spring breakers ${ }^{1}$, for example, have not visited the destination for three years in a row. Cruises have also reduced their arrivals; three years ago Acapulco used to receive 220 cruises and now it receives just 40. Kidnapping for ransom are issues that people in Acapulco experience every day and, although the situation seems to be changing positively and security is guaranteed in the tourism zone, authorities and service providers claim that a positive image will take some time to achieve (Pavón, 2013).

\section{Methods}

The aim of this research was to analyse the relationship between crime-related travel advice given by foreign governments and Mexico's destination image. Official government websites were selected for this analysis. This criterion was based on the assumptions that the Internet offers great potential to influence consumers' perceived images (Choi, et al., 2007) and that official government websites appear to be an ideal starting point for exploring the internet's potential to form destination image (Lepp, et al., 2011).

Content analysis of official websites was adopted as the technique for meeting the objective. In qualitative content analysis, "there is an emphasis on allowing categories to emerge out of data and on recognizing the significance for understanding meaning in the context in which an item being analysed (and the categories derived from it) appeared" (Bryman, 2008: 276). The analysis of websites was adopted since the use of official websites and other digital media has proved to be fruitful for the study of destination image and related issues. The internet has become a major medium in tourism marketing and has been actively used by the tourism industry (Stepchenkova \& Morrison, 2006), but also by governmental bodies with the interest of protecting their citizens as international travellers. Several digital information sources are potentially useful for the analysis of destination image related issues; these sources include, but

Table Details of websites used for the analysis of foreign travel advice to Mexico

\begin{tabular}{|c|c|c|c|}
\hline Country & Official body & Description & website \\
\hline United States & $\begin{array}{l}\text { The State Department's } \\
\text { Office of American Citi- } \\
\text { zens Services and Crisis } \\
\text { Management }\end{array}$ & $\begin{array}{l}\text { The Consular Information Pro- } \\
\text { gram informs the public of condi- } \\
\text { tions abroad that may affect their } \\
\text { safety and security. Country Spe- } \\
\text { cific Information, Travel Alerts, } \\
\text { and Travel Warnings are vital } \\
\text { parts of this program. }\end{array}$ & www.travel.state.gov/travel \\
\hline Canada & Government of Canada & $\begin{array}{l}\text { The Government of Canada web- } \\
\text { site for Canadians travelling or } \\
\text { living abroad. Find information } \\
\text { on destination safety and secu- } \\
\text { rity, local laws and customs, } \\
\text { entry requirements, health con- } \\
\text { ditions, and emergency contact } \\
\text { information for Canadian offices } \\
\text { around the world. }\end{array}$ & www.travel.gc.ca \\
\hline United Kingdom & $\begin{array}{l}\text { Foreign \& Commonwe- } \\
\text { alth Office }\end{array}$ & $\begin{array}{l}\text { The FCO promotes British inte- } \\
\text { rests overseas, supporting our } \\
\text { citizens and businesses around } \\
\text { the globe. }\end{array}$ & ww.fco.gov.uk \\
\hline Spain & $\begin{array}{l}\text { The Ministry of Foreign } \\
\text { Affairs and Cooperation }\end{array}$ & $\begin{array}{l}\text { Among other purposes, it is res- } \\
\text { ponsible for protecting Spanish } \\
\text { citizens abroad. }\end{array}$ & www.maec.es \\
\hline
\end{tabular}


are not limited to, search engines, travel and vacation websites, internet advertising, organisations' websites, social networking, blogs, online video sites, and newspaper websites (Divinagracia, et al., 2012).

Research on the internet as an image formation agent is still in its infancy. However, content analysis of digital sources as related to image formation is gaining popularity (Choi, et al., 2007). Content analysis has been utilised specifically, for example, to analyse positioning strategies in the USA (Lee, et al., 2006); to analyse techniques used to promote East Asian destinations' cuisine and food culture (Horng \& Tsai, 2010); to investigate images and risks associated with Uganda (Lepp, et al., 2011); to identify the image representations of Macau (Choi, et al., 2007); to study the interrelationships among electronic word of mouth, destination image, tourist attitude and travel intention (Jalilvand, et al., 2012); to examine visitors' online publishing in Isfahan (Çakmak \& Isaac, 2012); and to determine the role of digital images on consumer choices (Divinagracia, et al., 2012); among other aims.

The travel advice given on the official websites of the four most important countries for inbound tourism to Mexico, namely United States, Canada, United Kingdom and Spain, was considered for analysis (see Table 3). For content analysis, attention was focused specifically on messages. Messages are defined as "discernible units of text on a particular issue" (Crooks, et al., 2011), in this case such units ranged from a single word to a sentence or to several paragraphs.

\section{Findings}

The analysis of the selected websites suggests that travel advice about Mexico acknowledges that most visits to Mexico are troublefree. Particularly, official websites inform that the most important tourism destinations in the whole country do not face security problems, or at least do not experience the levels of crime reported in other areas. This has led foreign governments to state that there is no nationwide advisory in effect for Mexico.

Additionally, it is observed that governments recognise that many of their citizens have travelled to Mexico safely. In the case of the UK, for example, the government states that millions of foreign visitors, including thousands of British nationals, safely visit the country each year. Likewise, Canada points out that 1.5 million
Canadian citizens travel to Mexico each year, and the vast majority of these do so without incident. Additionally, it is commonly acknowledged that there is no evidence that foreign visitors are targeted based on their nationality. The advice seems to suggest that incidents that happen to foreign visitors are sometimes a matter of accident rather than planned actions. As the British government claims, "while British nationals are unlikely to be specifically targeted, there is always a risk of being in the wrong place at the wrong time".

However, whilst it is recognised that most of the country remains safe for foreign visitors, the information provided by governments suggests that certain parts of the country are insecure, but recognise that this is not necessarily exclusive to Mexico. This advice is given with regard to issues such as armed robbery, purse snatching, pickpocketing and assault, to mention some. This situation has led, for example, the Canadian government to advise their citizens to avoid walking after dark, to frequent bars and nightclubs as part of a group, to avoid hailing taxis on the street, to travel during daylight hours and on first-class buses only, and to avoid wearing expensive jewellery or watches.

However, analysis of the four official websites reveals that the security situation in Mexico goes beyond "common" crime issues. The governments of the four most important countries for inbound tourism to Mexico state that there are serious risks associated with organised crime that international travellers need to consider. A detailed review of the official websites shows that specific messages (words and ideas) frequently appear in the advice provided. As can be seen in Table 4, some of the messages that commonly appear in government travel advice about Mexico are largely associated with serious criminal activity.

These messages are a common component within the travel/tourism advice and warnings to foreign visitors. This is evidenced in the large and repetitive number of explicit messages in the websites. The following excerpts illustrate this:

"TCOs [Transnational Criminal Organisations] engage in narcotics trafficking and other unlawful activities throughout Mexico. The TCOs themselves are engaged in a violent struggle to control drug trafficking routes and other criminal activity. As a result, crime and violence are serious problems throughout the country and can occur everywhere. U.S. citizens have fallen victim to TCO activity, 
Table Selected crime-related messages regarding travel advice to Mexico. Source: Official websites selected for analysis

\begin{tabular}{|c|c|}
\hline \multicolumn{2}{|c|}{ Messages } \\
\hline - armed confrontations & - military and federal police forces \\
\hline - cartel violence & - narcotics trafficking \\
\hline - crime & - narcotics-related homicides \\
\hline - criminal activity & - organised crime \\
\hline - criminals posing as police officers & - organised criminal groups \\
\hline - deteriorating security situation & - physical and sexual assault \\
\hline - disappearances & - potentially dangerous regions \\
\hline - drug groups & - rapes \\
\hline - drug related violence and crime & - roadblocks \\
\hline - extreme levels of violence & - sexual offences \\
\hline - gun battles & - transnational criminal organisations \\
\hline - high levels of criminal activity & - violence \\
\hline - high levels of organised crime & - violent incidents \\
\hline - kidnappings & - violent struggle \\
\hline
\end{tabular}

including homicide, gun battles, kidnapping, carjacking and highway robbery" (www.travel.state.gov/travel, 08/03/2013).

"You should exercise a high degree of caution, especially in those parts of the country experiencing deteriorating security situation [...] High levels of criminal activity, as well as occasional illegal roadblocks demonstrations and protests remain a concern throughout the country" (www.travel.gc.ca, 08/03/2013).

"We advise against all but essential travel to Ciudad Juarez, where there is a high level of drug-related violence and criminal activity [...] Drug-related violence in Mexico has increased over the past year. In 2010, there were 15,273 victims of drug-related violence in Mexico compared to 9,614 in 2009" (ww. fco.gov.uk, 08/03/2013).

Based on the insecurity situation reported, the travel and tourism advice by governments seems to concur in terms of the areas and states that should be avoided in Mexico. There is particular attention to advice against visiting several northern and southern areas. The US Department of State, for example, advises US citizens to exercise caution in states such as Chihuahua, Durango, Nuevo León, San Luis
Potosí, Tamaulipas, Michoacán, and Guerrero, to mention but a few. Similar advice is given by the Canadian government, who also advise exercising caution when travelling outside some tourist areas. Based on the advice given by each of the governments analysed, Table 5 shows the specific advice that each government gives about visiting each of Mexico's states.

Analysis suggests that there are mainly three groups of advice, based on the level of caution needed during a visit. The first are those states, mainly located in the northern border region, that are definitely not recommended to citizens. The second are those states where visitors should exercise some kind of caution, and the third group is made up of those states that are trouble-free or that no advice or warning is given about. Figure 1 shows the distribution of the three groups.

Thus, it is important to notice that the advice given by governments to travellers is provided at different levels. When providing state-specific information reporting the highest numbers of drug related murders, The Foreign \& Commonwealth Office of the UK advises, for instance, "to exercise extreme caution" or "against all but essential travel" to specific areas in the country. Similarly, the US Department of State provides state-by-state assess- 
Table State-by-state travel advice by country

\begin{tabular}{|c|c|c|c|c|c|}
\hline State & United Sates & Canada & $\begin{array}{l}\text { United } \\
\text { Kingdom }\end{array}$ & \multicolumn{2}{|c|}{ Spain } \\
\hline 1 & Aguascalientes & DNET & NA & NA & $\mathrm{EC}$ \\
\hline 2 & ¡Error! Referencia de hipervínculo no válida. (North) & $\mathrm{EC}$ & $\mathrm{EC}$ & FVP & $\mathrm{TF}$ \\
\hline 3 & ¡Error! Referencia de hipervínculo no válida. & NA & NA & NA & $\mathrm{TF}$ \\
\hline 4 & ¡Error! Referencia de hipervínculo no válida. & NA & NA & NA & $\mathrm{TF}$ \\
\hline 5 & ¡Error! Referencia de hipervínculo no válida. & DNET & DNET & DNET & DNET \\
\hline 6 & ¡Error! Referencia de hipervínculo no válida. & NA & NA & FVP & $\mathrm{TF}$ \\
\hline 7 & Coahuila & DNET & DNET & FVP & DNET \\
\hline 8 & ¡Error! Referencia de hipervínculo no válida. & DNET & NA & NA & NA \\
\hline 9 & Durango & DNET & DNET & FVP & DNET \\
\hline 10 & Guerrero & DNET & $\mathrm{EC}$ & FVP & DNET \\
\hline 11 & Guanajuato & NA & NA & NA & $\mathrm{TF}$ \\
\hline 12 & Hidalgo & NA & NA & NA & $\mathrm{TF}$ \\
\hline 13 & Jalisco & DNET & $\mathrm{EC}$ & FVP & NA \\
\hline 14 & Michoacán & DNET & $\mathrm{EC}$ & FVP & DNET \\
\hline 15 & Mexico State & $\mathrm{EC}$ & NA & NA & $\mathrm{TF}$ \\
\hline 16 & ¡Error! Referencia de hipervínculo no válida. City & NA & NA & NA & NA \\
\hline 17 & Morelos & DNET & NA & NA & $\mathrm{EC}$ \\
\hline 18 & Nayarit & DNET & $\mathrm{EC}$ & FVP & NA \\
\hline 19 & Nuevo León & DNET & DNET & DNET & DNET \\
\hline 20 & Oaxaca & NW & NA & FVP & $\mathrm{TF}$ \\
\hline 21 & Puebla & NA & NA & NA & $\mathrm{TF}$ \\
\hline 22 & Quintana Roo & NA & NA & FVP & $\mathrm{TF}$ \\
\hline 23 & Querétaro & NA & NA & NA & $\mathrm{TF}$ \\
\hline 24 & San Luis Potosí & DNET & $\mathrm{EC}$ & FVP & NA \\
\hline 24 & Sinaloa & DNET & DNET & FVP & DNET \\
\hline 25 & Sonora & DNET & DNET & FVP & DNET \\
\hline 27 & Tabasco & NA & NA & NA & $\mathrm{TF}$ \\
\hline 28 & Tamaulipas & DNET & DNET & DNET & DNET \\
\hline 29 & Tlaxcala & NA & NA & NA & $\mathrm{TF}$ \\
\hline 30 & Veracruz & $\mathrm{EC}$ & $\mathrm{EC}$ & FVP & DNET \\
\hline 31 & Yucatán & NA & NA & NA & $\mathrm{TF}$ \\
\hline 32 & Zacatecas & DNET & $\mathrm{EC}$ & NA & $\mathrm{EC}$ \\
\hline
\end{tabular}

DNET $=$ Defer non-essential travel

$\mathrm{EC}=$ Exercise caution

FVP = No explicit advice is given but drug related violence is a problem

$\mathrm{NA}=$ No advisory in effect (The UK states that the omission of a particular state in the guidance does not however mean that the state in question is immune to drug-related violence)

NW = No warning in effect

$\mathrm{TF}=$ Trouble-free (with some specific cities within the state in question being the exception) 
Figure Mexico. State-by-state travel advice by official websites selected for analysis

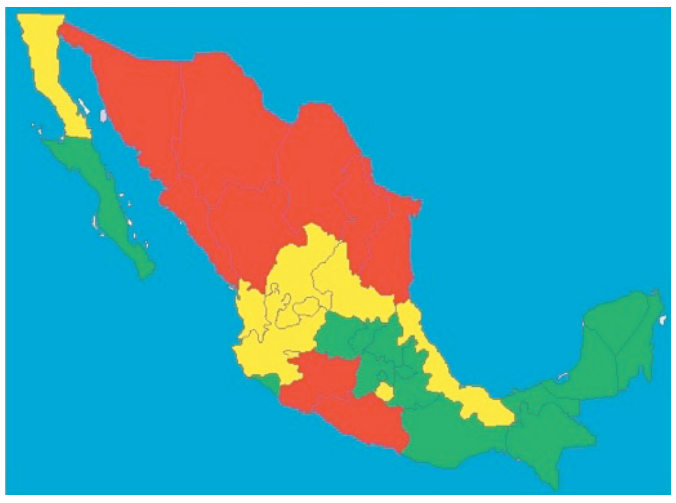

(Red $=$ Defer non-essential travel; Yellow = Exercise caution; Green $=$ No advice/warning or trouble-free)

ment by literally advising "to defer non-essential travel" and "to exercise caution" for a large number of states. "No advisory is in effect" and "No warning is in effect" also appear for specific destinations, particularly for those in which no significant organised crime-related activity has been reported.

Finally, the types of travel warnings about Mexico issued by official websites are largely based on the numbers of crime incidents reported. Some of these figures are directly related to tourism contexts. The UK, for example, advises extreme caution outside the main tourist areas in Acapulco based on the fact that six female Spanish tourists were raped in their rented beach house outside the main area of Acapulco in February 2013. Furthermore, the UK government has received reports of an Italian visitor raped by police officers in the resort of Playa del Carmen in the same month. In a similar vein, the US Department of State warns that crime and violence are serious problems throughout the country. It states that as a result of organised crime, US citizens have become victims of crime activity, including murders. More specifically, the website states that the number of US citizens reported as murdered in Mexico was 113 in 2011 and 32 in the first six months of 2012 .

\section{Implications}

The governments of the US, Canada, the UK and Spain, which are the most important countries for inbound tourism to Mexico, state that most visits to Mexico are incident-free.
Nevertheless, it can be easily observed that the official advice given by these countries is largely focused on criminal activity. The figures, reports and warnings related to crime and violence in Mexico are somehow overwhelming, compared to positive features of the country. Bearing in mind the possibility that official advice may be more reliable for both potential and actual travellers, the contribution of official websites to Mexico's destination image may not be as favourable as desired.

The type of foreign official information on insecurity in Mexico can make it difficult for the Mexican government to present a positive, uncontested image. While the efforts of Mexican governmental tourism agencies may be valuable, the advice and warning issued by the main tourism generating countries may have an important effect on forming cognitive and affective negative images. It is possible that the warnings about insecurity issued by foreign countries will negatively shape the beliefs, attitudes, and even feelings and emotions of potential travellers to Mexico. In turn, the perception of insecurity might contribute to decreasing the number of visits to the whole country, even to regions or destinations where criminal activity is not significant at all.

As a cognitive and emotional construct, images are not static. As suggested by the literature review, both intrinsic (e.g. motivations, previous experience) and extrinsic factors (e.g. websites, brochures) can determine destination image formation. With regard to the latter, special attention should be paid periodically to the very specific way that foreign official government websites are influencing or determining Mexico's image as an international tourism destination. Perhaps, more caution should be taken by foreign governments when reporting facts and figures about security issues in Mexico. Bearing in mind that Mexico is a relatively large country, it is highly questionable whether accurate facts and figures can be offered in terms of each of the thirty-two states that make up the whole country.

\section{Conclusions}

This paper aimed to analyse the travel advice given by foreign governments as related to crime and destination image in Mexico. By so doing, it reveals that governments state that most visitations to the country are trouble-free. However, in most cases the vast majority of travel advice is based on the security situation in 
Mexico, particularly organised crime. This was shown in the number of messages and specific warnings that are repeatedly written into official websites.

It has been argued that official government tourism websites may be useful for exploring the internet's potential to induce a favourable destination image (Lepp, et al., 2011). Yet, the internet also has potential to induce unfavourable images. This is so particularly when the internet, as an official source, is used by foreign governments to issue travel warnings about specific countries. As an international information source, governments' travel websites may affect a very large number of people including not only their citizens but also individuals from other parts of the world that have access to the internet. Additionally, the potential to induce negative destination image relies on the fact that official warnings are to some extent more credible than the information provided by other organic and induced sources.

As in other investigations, new research needs emerge. While qualitative content analysis has been validated as a research technique for the analysis of destination image, quantitative approaches need to be incorporated to corroborate, validate or reject the findings presented here. Longitudinal studies may also be useful for monitoring governments' travel advice. On a related issue, it is observed that the effect that induced information sources, including governments' official websites, has on image formation has not been sufficiently elucidated. This represents not only a research opportunity but also a need; if the effect of online information sources on image formation is investigated, more specific strategies can be adopted to improve benefits or reduce disadvantages of organic sources.

\section{References}

Bailey, J.

2010 "Combating organized crime and drug trafficking in Mexico: What are Mexican and U.S. Strategies?”. In E. Olson, D. A. Shirk \& A. Selee (Eds.), Shared Responsibility: U.S.Mexico policy options for confronting organized crime (pp. 327-349). San Diego: Woodrow Wilson International Center for Scholars Mexico Institute \& University of San Diego. Baloglu, S., \& McCleary, K. W. 1999 "A model of destination image formation". Annals of Tourism Research, 26(4): 868-897.
Beerli, A., \& Martín, J. D.

2004 "Factors influencing destination image". Annals of Tourism Research, 31(3): 657-681.

Brunt, P., Mawby, R., \& Hambly, Z.

2000 "Tourist victimisation and the fear of crime on holiday". Tourism Management, 21(4): 417-424.

Bryman, A.

2008 Social research methods (3 ed.). Oxford: Oxford University Press.

Çakmak, E., \& Isaac, R. K.

2012 "What destination marketers can learn from their visitors' blogs: An image analysis of Bethlehem, Palestine". Journal of Destination Marketing \& Management, 1(1-2): 124133.

\section{CESTUR}

2011 "Análisis sobre la lealtad del consumidor de destinos turísticos en México". Centro de Estudios Superiores en Turismo. Available at: www.cestur.sectur.gob.mx, accessed 05 March 2013.

Crooks, V. A., Turner, L., Snyder, J., johnston, R., \& Kingsbury, P.

2011 "Promoting medical tourism to India: Messages, images, and the marketing of international patient travel". Social Science \& Medicince, 72(5): 726-732.

Choi, S., Lehto, X. Y., \& Morrison, A. M.

2007 "Destination image representation on the web: Content analysis of Macau travel related websites". Tourism Management, 28(1): 118-119.

Chon, K.

1990 "The role of destination image in tourism: A review and discussion". The Tourist Review, 45(2): 2-9.

Data Tur

2013 "Llegada de visitantes internacionales vía aérea por principal nacionalidad". Secretaría de Turismo. Available at: www.datatur.sectur.gob.mx, accessed 05 March 2013.

Divinagracia, L. A., Divinagracia, M. R., \& Divinagracia, D. G.

2012 "Digital media-induced tourism: The case of nature-based tourism (NBT) at East Java, Indonesia”. Procedia - Social and Behavioral Sciences, 57(9): 85-94.

Echtner, C., \& Ritchie, J. R. B.

1991 "The meaning and measurement of destination image". The Journal of Tourism Studies, 2(2): 2-12.

Floyd, M. F. \& Pennington-Gray, L.

2004 "Profiling risk perceptions of tourists". Annals of Tourism Research, 31(4): 10511054. 
Gallarza, M. G., Gil, I., \& Calderón, H.

2002 "Destination image: Towards a conceptual framework". Annals of Tourism Research, 29(1): 56-78.

Gartner, W.

1993 "Image formation process". In M. Uysal \&

D. Fesenmaier (Eds.), Communication and channel systmes in tourism marketing (pp. 191-215). New York: Haworth Press.

Gartner, W., \& Shen, J.

1992 "The impact of Tiananmen Square on China's tourism image". Journal of Travel Research, 30(4): 47-52.

George, R.

2003 "Tourists' perceptions of safety and security while visiting Cape Town". Tourism Management, 24(5): 575-585.

Horng, J., \& Tsai, C.

2010 "Government websites for promoting East Asian culinary tourism: A cross-national analysis". Tourism Management, 31(1): 74-85. Jalilvand, M. R., Samiei, N., Dini, B., \& Manzari, P. Y.

2012 Examining the structural relationships of electronic word of mouth, destination image, tourist attitude toward destination and travel intention: An integrated approach. Journal of Destination Marketing \& Management, 1(12): 134-143.

Josiam, B. M., Hobson, J. S. P., Dietrich, U. C. and Smeaton, G.

1998 "An analysis of the sexual, alcohol, and drug related behavioural patterns of students on spring break". Tourism Management, 19(6): 501-513.

Korstanje, M.

2009 "Re-visiting risk perception theory in the context of travel". e-Review of Tourism Research, 7(4): 68-81.

Larsen, S., Brun, W. \& Øgaard, T.

2009 "What tourists worry about - Construction of a scale measuring tourist worries". Tourism Management, 30(2): 260-265.

Lee, G., Cai, L. A., \& O’Leary, J. T.

2006 "WWW.Branding.States.US: An analysis of brand-building elements in the US state tourism websites". Tourism Management, 27(5): 815-828.

Lepp, A., \& Gibson, H.

2003 "Tourist roles, perceived risk and international tourism". Annals of Tourism Research, 30(3): 606-624.

Lepp, A., Gibson, H., \& Lane, C.

2011 "Image and perceived risk: A study of Uganda and its official tourism website". Tourism Management, 32(3): 675-684.
Mohammed, S. N.

2004 "Self-presentation of small developing countries on the world wide web: a study of official websites". New Media and Society, 6(4): 469-486.

Pavón, Luis

2013 "Reportaje sobre turismo e inseguridad en Acapulco". Primero Noticias, 05 March 2013.

Pike, S.

2002 "Destination image analysis - a review of 142 papers from 1973 to 2000". Tourism Management, 23(5): 541-549.

SECTUR

2007 Programa Sectorial de Turismo 2007-2012. Mexico: Secretaría de Turismo.

\section{SECTUR}

2011 Quinto informe de labores. Secretaría de Turismo.

Sirakaya, E., Sheppard, A., \& McLellan, R.

1997 "Assessment of the relationship between perceived safety at a vacation site and destination choirce decisions: Extending the behavioral decision-making model". Journal of Hospitality and Tourism Research, 21(2): $1-10$.

Stepchenkova, S., \& Morrison, A. M.

2006 "The destination image of Russia: From the online induced perspective". Tourism Management, 27(5): 943-956.

UNODC

2013 Organized crime, from http://www.unodc. org/unodc/en/organized-crime/index.html

UNWTO

2000 Tourism 2020 vision. Americas. Madrid: World Tourism Organization.

UNWTO

2012 UNWTO Tourism Highlights. Madrid: World Tourism Organization.

Wall, G. \& Mathieson, A.

2006 Tourism. Change, impacts anf opportunities. Essex. Pearson.

\section{Notas}

1 Spring break is a tourism phenomenon consisting of a large number of students coming from the USA and Canada between February and March in sea-and-sun destinations in the USA, Mexico and the Caribbean (Josiam et al., 1998).

Recibido:

$15 / 04 / 2013$

Reenviado:

$30 / 05 / 2013$

Aceptado:

$01 / 07 / 2013$

Sometido a evaluación por pares anónimos 